\begin{tabular}{|l|l|l}
\hline & $\begin{array}{l}\text { Proceedings of the } \\
\text { Informing Science }+\end{array}$ & $\begin{array}{l}\text { An Official Publication } \\
\text { of the Informing Science Institute } \\
\text { InformingScience.org }\end{array}$ \\
\hline
\end{tabular}

Online July 7-8, 2020

\title{
SYSTEMATIC LITERATURE REVIEW TO IDENTIFY AND RANK THE MOST COMMON REASONS FOR PlagiaRISM
}

Frederik Hattingh*

Albertus Buitendag

Manoj Lall

* Corresponding author
Tshwane University of Technology, $\underline{\text { hattinghfg@tut.ac.za }}$ Pretoria, South Africa

Tshwane University of Technology, Pretoria, South Africa

Tshwane University of Technology, $\quad \underline{\text { lallm@tut.ac.za }}$ Pretoria, South Africa buitendagaak@,tut.ac.za

\section{ABSTRACT}

Aim/Purpose

Methodology

Contribution

Findings

Impact on Society
In this paper the authors explore and analyse the literature to determine the common reasons why a student may choose to plagiarise. The predominant purpose of the research formed part of a larger study to develop metrics and methods to identify potential plagiarism within coding-based assignments.

A systematic literature review with the objective to identify and rank the most common reasons for plagiarism was conducted. This was achieved by identifying primary studies conducted on the reasons for plagiarism. The identified studies were subsequently subjected to a top down quality assessment with a number of criteria. In total, 37 studies made it through the selection process. The results of the selected studies were synthesized to obtain a ranked list of reasons why students plagiarise.

This paper contributes a ranked list of reasons that may influence a student's decision to plagiarise, based on a set of categories emerging from the literature.

Eleven possible categories indicating the common reasons behind a student's decision to plagiarise are identified. The literature revealed that aspects such as the external values of the student and attitudes towards academia and teaching styles are significant factors that impact a student's willingness and decision to plagiarise.

Instructors may gain a better understanding on why their students decided to plagiarise.

Accepted by Editor Michael Jones | Received: February 6,2020 | Revised: June 2, 2020 | Accepted: June 16, 2020.

Cite as: Hattingh, F., Buitendag, A., \& Lall, M. (2020). Systematic literature review to identify and rank the most common reasons for plagiarism. In M. Jones (Ed.), Proceedings of InSITE 2020: Informing Science and Information Technology Education Conference, pp. 159-182. Informing Science Institute. https://doi.org/10.28945/4576

(CC BY-NC 4.0) This article is licensed to you under a Creative Commons Attribution-NonCommercial 4.0 International License. When you copy and redistribute this paper in full or in part, you need to provide proper attribution to it to ensure that others can later locate this work (and to ensure that others do not accuse you of plagiarism). You may (and we encourage you to) adapt, remix, transform, and build upon the material for any non-commercial purposes. This license does not permit you to use this material for commercial purposes. 
Most Common Reasons for Plagiarism

Keywords students' attitudes towards plagiarism, plagiarism metrics, plagiarism deterrents

\section{INTRODUCTION}

The predominant characteristic of the information age is the large scale "computerisation of information" (Carr, 2006). As a direct result of the technological advances brought about by what has generally become known as 'the information age', the way students acquire knowledge has either changed or is already changing to some degree. Aasheim et al. (2012) hypothesized that students have different perceptions about what constitutes academically dishonest activities and behaviour in relation to programming assignments, as opposed to assignments involving maths and essays.

The Internet is the main advancement of the information age and thus had a significant impact on education. The increased rapid access to information does bring some advantages, but academics are increasingly worrying about the effect this is having on students plagiarizing (Austin \& Brown, 1999; M. Jones \& Sheridan, 2014).

Helgesson and Erikson (2015) define plagiarism as: "using someone else's intellectual product (such as texts, ideas, or results), thereby implying that it is their own." It is pointed out that using the intellectual product of another without proper attribution may happen intentionally or sometimes unintentionally (Das \& Panjabi, 2011).

\section{RESEARCH PROBLEM}

An academic institution may use proactive plagiarism prevention methods to try and discourage plagiarism from taking place. The institution may also choose to use a reactive method like plagiarism detection combined with disciplinary action to limit future plagiarism. Both proactive and reactive approaches and their respective techniques applied to prevent or detect plagiarism, present problems that need to be examined and addressed (Ganguly et al., 2018; Haskins \& Pieterse, 2016; Louw \& Pieterse, 2015; Portillo-Dominguez et al., 2017).

Reactive plagiarism prevention measures do not show why a student may have plagiarised work. After submission the instructor will make the final determination on whether a student plagiarised code by analysing the metrics produced by the plagiarism detection engine. A 'metric' is described as a rule that can convert a document into a numeric value for representing similarity when compared to other documents (Lancaster \& Culwin, 2004). When the instructor reviews the metrics, the focus is often only on finding cases where definite plagiarism has occurred. With metrics from traditional detection engines the instructor cannot determine why the student chose to plagiarise in the first place.

According to Devlin and Gray (2007) the only way for the instructor to determine the reason for plagiarism occurring is to conduct detailed interviews with the students. Because there is no timeline of how the student constructed the body of work, any direct evidence that the student tried to conceal when plagiarising the assignment is also lost.

With the above in mind it was possible to distil the multitude of problems as follows into one single problem statement: "General plagiarism detection engines give no clue about why the student plagiarised and do not add any value to teaching and learning education." To investigate the problem, the researchers set two main objectives. The first of these objectives is presented as part of this paper. The result from investigating the first objective will be used to investigate the second objective in later research work. 


\section{RESEARCH QUESTION AND OBJECTIVES}

When embarking with a research project, the researcher formulates and classifies the research question as the first step to selecting the correct research design (Easterbrook et al., 2008).

The research question to be addressed was formulated as follows:

How can a real-time plagiarism detection engine be designed to produce metrics that can assist in plagiarism detection and support student education on plagiarism?

Two different types of research question classifications often found in research are exploration and design type questions. It was identified by the researchers that the above research question can be classified to belong to both areas. The first area is of an exploratory nature with the second one being of type design. These areas respectively entail the following:

- The exploratory question can be answered by investigating different aspects connected to plagiarism and using the conclusions from this, to later identify metrics that can be used in real-time plagiarism detection.

- The design question relies on the conclusions reached from investigating the exploratory questions to start the design process. This especially focuses on what metrics a real-time plagiarism detection engine needs to generate. It then asks how one would design such an engine to make full use of these metrics.

Both areas referred to above are represented in the research question. Therefore, the choice fell on the application of a mixed method research approach. The mixed method approach allowed for the most applicable methodology to be used to answer each question area. Consequently, the mixed method approach applied here consisted of a systematic literature review to explore, identify, and apply a design science effort to design.

This paper presents the exploratory area of the mixed method approach in the form of a systematic literature review with the objective to identify and rank the most common reasons for plagiarism. It is hoped that the results of reaching this objective can provide a theoretical base to build on during the design science process for objective two to follow as part of a later research effort.

\section{METHODOLOGY}

In general a literature review is defined as "the analysis, critical evaluation and synthesis of existing knowledge relevant to your research problem, thesis or the issue that you are aiming to say something about" (C. Hart, 2018, pp. 3-4). Viewed from the perspective of function, Ridley (2012, p. 5) identifies three types of literature reviews, namely, the traditional review, the standalone review, and the systematic evidence-based review. The traditional review serves as the starting point of some primary research. The standalone review consists only of a literature review and its resulting insights. The systematic evidence-based review comprises an overview of all the available primary research studies from a particular field.

Cronin et al. (2008) explain that the traditional literature review will provide the reader with thorough background information and point out new research developments on the research topic. The focus will be broad, covering both the topic and related material. Both Ridley (2012) and Cronin et al. (2008) clearly distinguish between a traditional review and a systematic (evidence-based) review.

As stated by Cronin et al. (2008), unlike traditional narrative literature reviews, the systematic review needs to be more structured, delineated, and follow a step by step approach that can be explained and validated. Briner and Deyner (2012) and Briner et al. (2009) argue that a traditional literature review differs from a systematic review in five distinct ways. Firstly, the question that a systematic review is going to address is well defined and answerable. Secondly, the question under review is constructed and investigated from the perspective of many stakeholders. Thirdly, the literature re- 
viewed comes from an extensive search into not only published, but also unpublished work. Fourthly, to ensure that bias to the researcher's own opinion is eliminated, the criteria for work to be included in the study is determined at the start of the study. Finally, the results from a systematic review are presented in such a manner that other researchers can validate the findings for themselves.

Although a systematic review does not provide direct answers, it will give the most accurate depiction of the question under review (Briner et al., 2009). The advantage of a systematic review is that bias is less likely. Another advantage is that the researcher can base results on many different methodologies and approaches used in the primary research. Because a systematic review combines the results from different studies, it is easier to detect smaller effects not immediately evident in the original individual studies (Kitchenham \& Charters, 2007).

When analysing the different approaches to conducting a good quality systematic literature review, there are some interpretation and execution differences (Alderson et al., 2004; D. Evans \& Pearson, 2001; Khan et al., 2003; Kitchenham \& Charters, 2007; Okoli \& Schabram, 2010). Yet, a pattern emerges that shows some agreement on the different steps to be followed. A well-defined question and problem should be the starting point for the systematic review. Using the question and problem as a framework, an initial literature search may then proceed. The studies identified during the initial literature search, should firstly be assessed for quality and then collectively synthesised. This is followed by discussing the synthesised results in the research report.

By combining different elements form the work of Khan et al. (2003), Alderson et al. (2004), Kitchenham and Charters (2007), Okoli and Schabram (2010) and D. Evans and Pearson (2001) a sequential approach to conducting a systematic literature review was constructed consisting of the six sequential steps indicated in Figure 1.

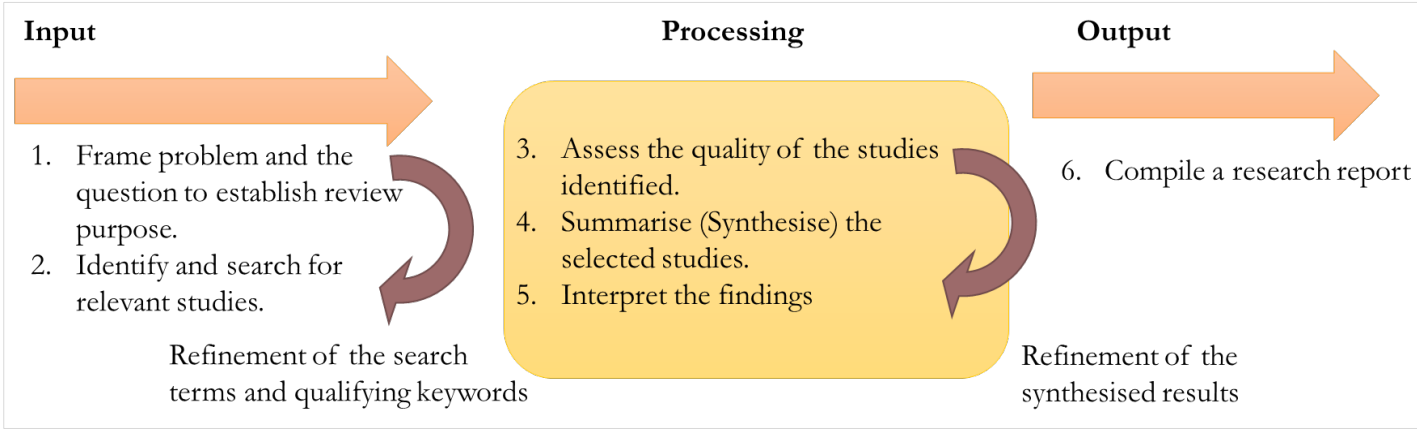

Figure 1: Sequential steps to conduct systematic literature review

In moving forward with this research, the results from conducting steps two through five are presented. By discussing the research problem, research questions and objectives earlier, the purpose of the systematic review is clarified. Thus, in executing the first step in the systematic review stated as to frame the problem and the question to establish the review purpose, the purpose of the review is described as to identify why students choose to plagiarise, and subsequently to develop metrics substantiated, grounded, and validated from the literature that would align with these reasons. This was followed by the next step, namely, to search and identify studies for inclusion in the systematic literature review.

\section{IDENTIFYING AND SEARCHING RELEVANT STUDIES}

With a clear purpose established for the systematic review, the second step in the process was to identify existing studies to the included. The purpose of this step was not to judge the quality or analyse any of the identified studies, but rather to create a reproducible search protocol. Initially a very broad search was conducted, and the results were analysed to construct a number of search terms. 
The search terms were then used to search different academic databases for specific applicable literature.

\section{THE INITIAL SEARCH}

The goal of the initial search was to discover and identify search phrases and keywords that were to be used in the later detailed search of academic databases. The starting point of this initial discovery search was Google Scholar. The specific search parameters used for the initial Google Scholar search were to exclude patents while including citations. The date filter was set to anytime and the results were sorted by relevance. An initial search was conducted with the search phrase "why do students plagiarise" using the search parameters mentioned above. This initial search yielded a total of 19,400 results. To further refine and to discover more search terms and keywords, the abstracts of the first 50 results were reviewed and analysed. From this analysis additional search terms and keywords were derived.

\section{KEYWORD AND SEARCH TERM ANALYSIS}

Additional keywords identified from the initial search included 'perception', 'qualitative', 'analysis', 'interview', 'empirical', 'understanding', 'questionnaire', 'intervention', 'cheating', 'discussion groups', 'cultural values', 'view', 'reasons', and 'survey'. The search terms shown in Figure 2 were developed to place these keywords into context:

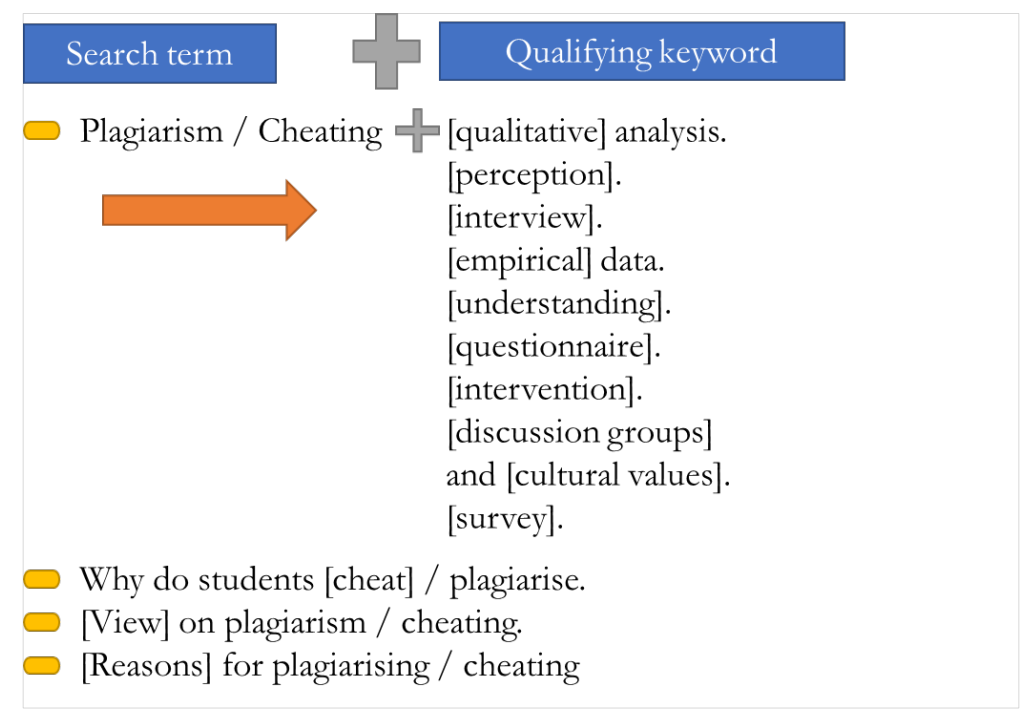

Figure 2: Search terms and qualifying keywords

The newly identified keywords and search phrases were subsequently used to search three academic databases.

\section{SEARCHING ACADEMIC DATABASES}

In total, three academic databases/search engines/digital libraries were searched by using the identified search phrases. Although it is technically correct to use the phrase 'search engine', for Google Scholar, 'digital library' for EBSCOhost, and 'database' for Sabinet African Journals, for the sake of brevity, they will collectively be referred to as 'databases' in this document. Google Scholar and EBSCOhost were selected due to their multidisciplinary nature and large collections of journal articles and conference proceedings. To get the African perspective, Sabinet African Journals was included in the search effort as, according to the database maintainers, "This service is the most comprehensive, 
searchable collection of full-text African electronic journals available on one platform which focuses on information originating from or pertaining to Africa" (Mitchell, n.d.).

When available in the search parameters (settings) patents, books, pamphlets, citations, and similar content were excluded. In all cases the search results were limited to content published after and including the year 1995. The only source that specifically mandated that individual databases be specified before searching was EBSCOhost. In this case most databases were excluded due to them not being relevant (example American Doctoral Dissertations, 1933 - 1955). The relevant internal databases that were selected in EBSCOhost were Academic Search Premier, CAB Abstracts, and Library, Information Science \& Technology Abstracts. For most databases, the full text option was selected and, if available, it was indicated that only peer reviewed or peer accredited publications should be returned. Where possible, the results were limited to English and sorted by relevance as determined by the database.

Using the search parameters, each database was searched with the search terms identified. Table 1 shows the total amount of results returned for each search term by each of the databases searched. The search order was EBSCOhost, Sabinet African Journals, and finally Google Scholar. With Google Scholar and Sabinet African Journals it was possible to use the original search term using free text search. EBSCOhost returned more relevant results if a Boolean search was used. For this reason, the original search term was modified and converted to a Boolean format where necessary. Both Google Scholar and EBSCOhost returned at least one unique paper for every search term. Sabinet African Journals returned unique papers for the first five search terms, but it was clear that the resource was exhausted by search term six as no further unique results were returned.

Table 1: Search results from academic databases

\begin{tabular}{|c|c|c|c|c|c|}
\hline $\begin{array}{c}\text { Original } \\
\text { Search } \\
\text { Term }\end{array}$ & $\begin{array}{l}\text { Modified for } \\
\text { search require- } \\
\text { ments }\end{array}$ & $\begin{array}{c}\text { Academic data- } \\
\text { base }\end{array}$ & Results returned & $\begin{array}{l}\text { Unique Pa- } \\
\text { pers Import- } \\
\text { ed }\end{array}$ & Tag Code \\
\hline \multirow{3}{*}{$\begin{array}{l}\text { Plagiarism } \\
\text { Cheating } \\
\text { qualitative } \\
\text { analysis }\end{array}$} & \multirow{3}{*}{$\begin{array}{c}\text { (Plagiarism OR } \\
\text { Cheating) AND } \\
\text { qualitative analysis }\end{array}$} & $\begin{array}{c}\text { Sabinet African } \\
\text { Journals }\end{array}$ & 18 & 8 & SABNE1 \\
\hline & & Ebscohost & 50 & 18 & EBS1 \\
\hline & & Google Scholar & 6230 & 16 & SCOL1 \\
\hline \multirow{3}{*}{$\begin{array}{l}\text { Plagiarism } \\
\text { Cheating } \\
\text { perceptions }\end{array}$} & \multirow{3}{*}{$\begin{array}{c}\text { (Plagiarism OR } \\
\text { Cheating) AND } \\
\text { perceptions }\end{array}$} & $\begin{array}{c}\text { Sabinet African } \\
\text { Journals }\end{array}$ & 25 & 6 & SABNE2 \\
\hline & & Ebscohost & 276 & 30 & EBS2 \\
\hline & & Google Scholar & 15100 & 29 & SCOL2 \\
\hline \multirow{3}{*}{$\begin{array}{l}\text { Plagiarism } \\
\text { Cheating } \\
\text { interviews }\end{array}$} & \multirow{3}{*}{$\begin{array}{c}\text { (Plagiarism OR } \\
\text { Cheating) AND } \\
\text { interviews }\end{array}$} & $\begin{array}{c}\text { Sabinet African } \\
\text { Journals }\end{array}$ & 15 & 2 & SABNE3 \\
\hline & & Ebscohost & 68 & 9 & EBS3 \\
\hline & & Google Scholar & 11900 & 23 & SCOL3 \\
\hline \multirow{3}{*}{$\begin{array}{l}\text { Plagiarism } \\
\text { Cheating } \\
\text { empirical data }\end{array}$} & \multirow{3}{*}{$\begin{array}{c}\text { (Plagiarism OR } \\
\text { Cheating) AND } \\
\text { empirical data }\end{array}$} & $\begin{array}{c}\text { Sabinet African } \\
\text { Journals }\end{array}$ & 15 & 2 & SABNE4 \\
\hline & & Ebscohost & 5 & 2 & EBS4 \\
\hline & & Google Scholar & 7380 & 19 & SCOL4 \\
\hline \multirow{3}{*}{$\begin{array}{l}\text { Plagiarism } \\
\text { Cheating } \\
\text { understand- } \\
\text { ing }\end{array}$} & \multirow[t]{3}{*}{$\begin{array}{c}\text { Plagiarism OR } \\
\text { Cheating) AND } \\
\text { understanding }\end{array}$} & $\begin{array}{c}\text { Sabinet African } \\
\text { Journals }\end{array}$ & 43 & 1 & SABNE5 \\
\hline & & Ebscohost & 155 & 22 & EBS5 \\
\hline & & Google Scholar & 16500 & 13 & SCOL5 \\
\hline
\end{tabular}




\begin{tabular}{|c|c|c|c|c|c|}
\hline $\begin{array}{c}\text { Original } \\
\text { Search } \\
\text { Term }\end{array}$ & $\begin{array}{l}\text { Modified for } \\
\text { search require- } \\
\text { ments }\end{array}$ & $\begin{array}{c}\text { Academic data- } \\
\text { base }\end{array}$ & Results returned & $\begin{array}{l}\text { Unique Pa- } \\
\text { pers Import- } \\
\text { ed }\end{array}$ & Tag Code \\
\hline \multirow{3}{*}{$\begin{array}{c}\text { Plagiarism } \\
\text { Cheating } \\
\text { questionnaire }\end{array}$} & \multirow{3}{*}{$\begin{array}{c}\text { Plagiarism OR } \\
\text { Cheating) AND } \\
\text { questionnaire }\end{array}$} & $\begin{array}{c}\text { Sabinet African } \\
\text { Journals }\end{array}$ & 23 & 0 & - \\
\hline & & Ebscohost & 110 & 29 & EBS6 \\
\hline & & Google Scholar & 15500 & 12 & SCOL6 \\
\hline \multirow{3}{*}{$\begin{array}{c}\text { Plagiarism } \\
\text { Cheating } \\
\text { Intervention }\end{array}$} & \multirow{3}{*}{$\begin{array}{c}\text { (Plagiarism OR } \\
\text { Cheating) AND } \\
\text { Intervention }\end{array}$} & $\begin{array}{c}\text { Sabinet African } \\
\text { Journals }\end{array}$ & 10 & 0 & - \\
\hline & & Ebscohost & 56 & 9 & EBS7 \\
\hline & & Google Scholar & 8030 & 19 & SCOL7 \\
\hline \multirow{3}{*}{$\begin{array}{l}\text { Why do } \\
\text { students } \\
\text { cheat plagia- } \\
\text { rise }\end{array}$} & \multirow{3}{*}{$\begin{array}{l}\text { (Plagiarism OR } \\
\text { Cheating) AND } \\
\text { why }\end{array}$} & $\begin{array}{c}\text { Sabinet African } \\
\text { Journals }\end{array}$ & 30 & 0 & - \\
\hline & & Ebscohost & 69 & 14 & EBS8 \\
\hline & & Google Scholar & 16000 & 6 & SCOL8 \\
\hline \multirow{3}{*}{$\begin{array}{l}\text { Plagiarism } \\
\text { Cheating } \\
\text { discussion } \\
\text { groups }\end{array}$} & \multirow{3}{*}{$\begin{array}{c}\text { (Plagiarism OR } \\
\text { Cheating) AND } \\
\text { discussion groups }\end{array}$} & $\begin{array}{c}\text { Sabinet African } \\
\text { Journals }\end{array}$ & 31 & 0 & - \\
\hline & & Ebscohost & 25 & 4 & EBS9 \\
\hline & & Google Scholar & 16700 & 9 & SCOL9 \\
\hline \multirow{3}{*}{$\begin{array}{l}\text { Plagiarism } \\
\text { Cheating and } \\
\text { cultural } \\
\text { values }\end{array}$} & \multirow{3}{*}{$\begin{array}{c}\text { (Plagiarism OR } \\
\text { Cheating) AND } \\
\text { cultural values }\end{array}$} & $\begin{array}{c}\text { Sabinet African } \\
\text { Journals }\end{array}$ & 31 & 0 & - \\
\hline & & Ebscohost & 21 & 1 & EBS10 \\
\hline & & Google Scholar & 14300 & 23 & SCOL10 \\
\hline \multirow[t]{3}{*}{$\begin{array}{c}\text { View on } \\
\text { plagiarism } \\
\text { cheating }\end{array}$} & \multirow{3}{*}{$\begin{array}{c}\text { (Plagiarism OR } \\
\text { Cheating) AND } \\
\text { views }\end{array}$} & $\begin{array}{c}\text { Sabinet African } \\
\text { Journals }\end{array}$ & 38 & 0 & - \\
\hline & & Ebscohost & 103 & 13 & EBS11 \\
\hline & & Google Scholar & 13400 & 19 & SCOL11 \\
\hline \multirow{3}{*}{$\begin{array}{l}\text { Reasons for } \\
\text { plagiarising } \\
\text { cheating }\end{array}$} & \multirow{3}{*}{$\begin{array}{c}\text { (Plagiarism OR } \\
\text { Cheating) AND } \\
\text { reasons }\end{array}$} & $\begin{array}{c}\text { Sabinet African } \\
\text { Journals }\end{array}$ & 44 & 0 & - \\
\hline & & Ebscohost & 100 & 19 & EBS12 \\
\hline & & Google Scholar & 1980 & 58 & SCOL12 \\
\hline \multirow[t]{3}{*}{$\begin{array}{l}\text { Plagiarism } \\
\text { cheating } \\
\text { survey }\end{array}$} & \multirow[t]{3}{*}{$\begin{array}{c}\text { (Plagiarism OR } \\
\text { Cheating) AND } \\
\text { survey }\end{array}$} & $\begin{array}{c}\text { Sabinet African } \\
\text { Journals }\end{array}$ & 21 & 0 & - \\
\hline & & Ebscohost & 151 & 18 & EBS13 \\
\hline & & Google Scholar & 14400 & 19 & SCOL13 \\
\hline
\end{tabular}

To avoid adding duplicate papers from multiple sources, each paper identified was assigned a unique tag code. This tag code indicated where the paper was first found and with what search term it was found. This tagging process was managed by the Paperpile reference manager (https://paperpile.com/). Once a paper was tagged and imported, the paper was not imported a second time if that paper was previously found in a different source or with a different search term.

For each search term the titles for the first fifty results were evaluated for possible inclusion. This initial evaluation was based on the title and in the case of some sources a small snippet of text pre- 
sented with the title. The evaluation protocol at this stage was not strict as the goal was to obtain as many relevant papers as possible. Searching the academic databases resulted in finding many initial papers that needed to be reviewed and subjected to a final thorough selection process as part of a quality assessment.

\section{QUALITY ASSESSMENT AND SELECTING STUDIES}

The third step in the systematic review process is to scrutinise all studies found (the corpus) when searching the different academic databases. Each study was subjected to a defined criterion for inclusion or exclusion. In this case the criteria for including or excluding literature were created and applied by a single researcher. This avoided a common problem as explained by Mallett et al. (2012) and Dhillon and Gill (2014) that in large research teams, the criteria may be interpreted differently by each member evaluating the research corpus. The abstracts for all papers identified in the academic databases using the search terms, were reviewed according to the criteria in Figure 3. If an abstract did not provide the required information, the full text was reviewed. In almost all cases it was necessary to evaluate the methodology section.

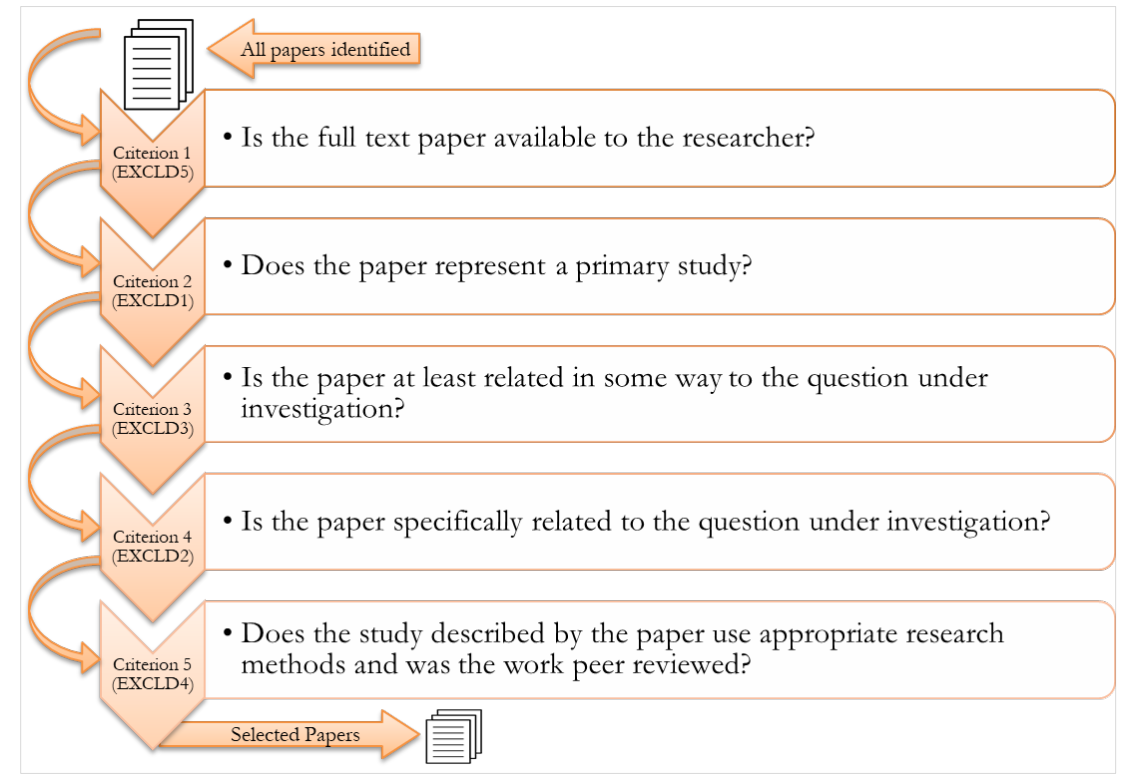

Figure 3: Selection criteria applied to papers for inclusion in the study

The criteria applied for each paper was subjected to a top down approach. If the paper made it through all the selection criteria, it was included in the study. In total, each paper was subjected to five criteria that could disqualify a paper for inclusion. Four of the criteria were based on quality, with one criterion based on accessibility. Each paper that was disqualified was assigned a unique tag code in the Paperpile reference manager for future reference. Table 2 contains detailed reasons that would have excluded a paper categorised according to the exclusion tag code.

The first criterion (EXCLD1) that could exclude a paper was one of accessibility. The full text for some papers identified was not accessible. Every effort was made to obtain these papers through official channels. 
Table 2: Reasons for excluding paper from study

\begin{tabular}{|c|c|}
\hline Code & Reason \\
\hline EXCLD1 & - Full paper not available \\
\hline EXCLD2 & - Study not related to broad research topic of plagiarism. \\
\hline EXCLD3 & $\begin{array}{l}\text { - Not primary study. } \\
\square \quad \text { Review previous literature to determine other implications or synthesising studies by } \\
\text { means of meta-analysis. } \\
\quad \text { Views based on previous studies or new insights, arguments or models by reinterpret- } \\
\text { ing previous primary studies. } \\
\square \quad \text { Introducing, defining and explaining concepts based on previous primary studies. } \\
\quad \text { Determinations made on why students plagiarized, based on other topics under inves- } \\
\text { tigation (thus not from primary data but rather an effect observed). } \\
\quad \text { Applying new concepts, arguments to an existing model or framework and drawing } \\
\text { new conclusions. } \\
\quad \begin{array}{l}\text { Making arguments, recommending some action or defining new methods to deal with } \\
\text { plagiarism, based on anecdotal, personal or institutional experience. }\end{array} \\
\text { Making arguments or recommending some action or way forward based on reviewing } \\
\text { literature. }\end{array}$ \\
\hline EXCLD4 & $\begin{array}{l}\text { - Research study not aligned with question under investigation. } \\
\text { Investigating the impact of educating students, providing policy statements, honour } \\
\text { codes, or using plagiarism detection tools on academic dishonesty. } \\
\text { Paper investigates types of plagiarism, general perceptions of plagiarism, general cheat- } \\
\text { ing behaviour or cheating behaviour in different learning environments, with very little } \\
\text { or no focus on why students plagiarise. } \\
\text { Evaluating a specific plagiarism prevention system or technique or some plagiarism } \\
\text { prevention system or technique to support plagiarism education or to investigate the } \\
\text { impact on students. } \\
\text { Retroactively scanning students or journal content for plagiarism prevalence and re- } \\
\text { porting on results. } \\
\text { Reporting on very narrow and specific cheating scenarios or factors. } \\
\text { Seek to establish a link between individual traits, personality, ethical matters, cheating } \\
\text { behaviour or moral reasoning and a cheating plagiarism in general. } \\
\quad \text { Exploring the relation between participating in academic dishonesty and later unethical } \\
\text { behaviour or as future indicator in professional practice. } \\
\quad \text { Identifies what students or academic staff regard as plagiarism and grades the serious- } \\
\text { ness of the perceived plagiarism, tests the student knowledge of plagiarism before or } \\
\text { after plagiarism/cheating education. } \\
\quad \text { Explores the response from academic staff to plagiarism including general awareness of } \\
\text { policies and other holistic prevention efforts. } \\
\text { Study exploring statistical methodologies using plagiarism as an example. }\end{array}$ \\
\hline EXCLD5 & $\begin{array}{l}\text { - Study used questionable research methods or research methods that produce data not easily } \\
\text { interpreted. } \\
\text { - } \quad \text { Study used extremely small population size. } \\
\text { - } \quad \text { Data not presented fully or only presented in a condensed form, thus not allowing reinter- } \\
\text { - Journal or conference paper of questionable quality. } \\
\text { - } \quad \text { Research not subjected to peer review, working papers, white papers, newspaper articles etc. }\end{array}$ \\
\hline
\end{tabular}

The second criterion (EXCLD2) was to establish if the paper under review was in some way related to the broad topic under investigation. This criterion did not serve to limit results relating to the question under investigation (why students plagiarise) but rather filtered out papers that were in no way related to the broad topic of plagiarism and cheating. As the initial list of papers up for selection was added with the goal to review as many papers as possible and the keywords selected for the 
search were rather broad, some papers initially selected in the first round were later found not to be related to the general topic.

The third criterion (EXCLD3) checked if the paper was a primary study. Systematic reviews rely on the summation of primary studies. Many papers identified and subsequently excluded, contained views based on previous studies or arrived at new insights, made new arguments, or constructed models by reinterpreting previous primary studies (Austin \& Brown, 1999; Flowerdew \& Li, 2007; M. Hart \& Friesner, 2004; Howard, 1995; McCabe et al., 2001; Valentine, 2006; Whitley, 1998). Papers were also found to make arguments, recommend some action, or define new methods to deal with plagiarism based on anecdotal, personal or institutional experience (Bachore, 2015; Briggs, 2003; Conradson \& Hernández-Ramos, 2004; Gerhardt, 2006; Harris, 2002; Howell et al., 2009; Kiehl, 2006; McCabe \& Stephens, 2006; McDowell \& Brown, 2001; Rowe, 2004; Scanlan, 2006; Thomas \& Sassi, 2011; Vaka'uta, 2008). Once a paper was found to be based on primary data the fourth criterion was applied.

The fourth criterion (EXCLD4) focussed on refining the remaining papers and selecting only those closely related to the question under investigation. With this criterion the goal was to exclude studies that were not specifically reporting either in full or as a component part on reasons for plagiarism.

Papers found not suitable investigated types of plagiarism, general perceptions of plagiarism, general cheating behaviour, or cheating behaviour in different learning environments, with little or no focus on why students plagiarise (Baruchson-Arbib \& Yaari, 2004; Grijalva et al., 2006; Lim \& See, 2001; Marshall \& Garry, 2005, 2006; Pecorari, 2003; Scanlon \& Neumann, 2002; Sheard \& Dick, 2011).

Papers would investigate a specific plagiarism prevention system, technique, or tool, including honour codes or using policy statements to support plagiarism education, or to investigate the impact of plagiarism prevention activities on students (Betts et al., 2012; Bing et al., 2012; Bretag et al., 2014; Chao et al., 2009; R. Evans, 2006; Graham-Matheson \& Starr, 2013; LaSalle, 2009; Ledwith \& Rísquez, 2008; Stapleton, 2012; Sutherland-Smith, 2005). Some papers also evaluated plagiarism education activities by testing students' knowledge of plagiarism before or after educating students on plagiarism or academic cheating (Belter \& du Pré, 2009; Ercegovac, 2005; Roig, 2001; Smedley et al., 2015; Yeo, 2007).

Other papers focussed on the psychology of academic dishonesty. The goal here was to establish a link between individual traits, personality, ethical matters, cheating behaviour, or moral reasoning and cheating or plagiarism in general (Clegg \& Flint, 2006; Coyne \& Thomas, 2008; East, 2009; Etter et al., 2006; Ferrari, 2005; Jackson et al., 2002; Thorpe et al., 1999; Williams et al., 2010). Somewhat related papers were also found that explored the relation between academic dishonesty and later unethical behaviour or, inversely, current academic dishonesty as a future indicator of unethical behaviour in professional practice (Lawson, 2004; Martin, 2005; Mirshekary \& Lawrence, 2009). Papers were not only focussed on students, but also dealt with staff by investigating the response from academic staff to plagiarism, including generally their awareness of policies and other holistic prevention efforts in the academic institution (Coren, 2011; Macdonald \& Carroll, 2006; Parameswaran \& Devi, 2006; Willen, 2004).

In applying the fifth criterion (EXCLD5), the remaining papers not excluded by the first four criteria, were subjected to a final thorough check focusing on the methodology applied and the quality of the publication that contained the paper. In this regard, although this does not necessarily reflect on the final conclusion reached, studies using an extremely small population size were excluded (Bamford \& Sergiou, 2005; Li \& Casanave, 2012; Love \& Simmons, 1998). Studies were also found that did not present the data gathered fully or only presented gathered data in a condensed form, thus not allowing reinterpretation (Flint, 2005; Ma et al., 2007; Pupovac et al., 2008; Sutherland-Smith, 2005). Such studies were also excluded. Finally, all papers were excluded that were not subjected to peer review (Hayes, 2003; Slobogin, 2002). 
By assessing the papers initially identified according to the five-exclusion criteria a large number of studies was excluded from the final two steps of the systematic review.

\section{SUMMARY AND SYNTHESIS OF THE SELECTED STUDIES}

In selecting the studies to be used in this research, a total of 37 studies made it through the selection process and were further investigated for the purpose of synthesis and summary as part of step 4 in the systematic literature review process. When and where the data were collected, and the sample size for each study was summarized to indicate the study year distribution, the representation level of different geographical areas, and average sample size.

\section{SUMMARY OF SELECTED STUDIES}

If it was not specifically stated in a paper during which year the data were collected, the paper publication year was used. For the most part, Figure 4 shows that the selected papers were distributed evenly over the years of the study search limit of between 1995 and 2015. Most papers used (29) were published between 2010 and 2015.

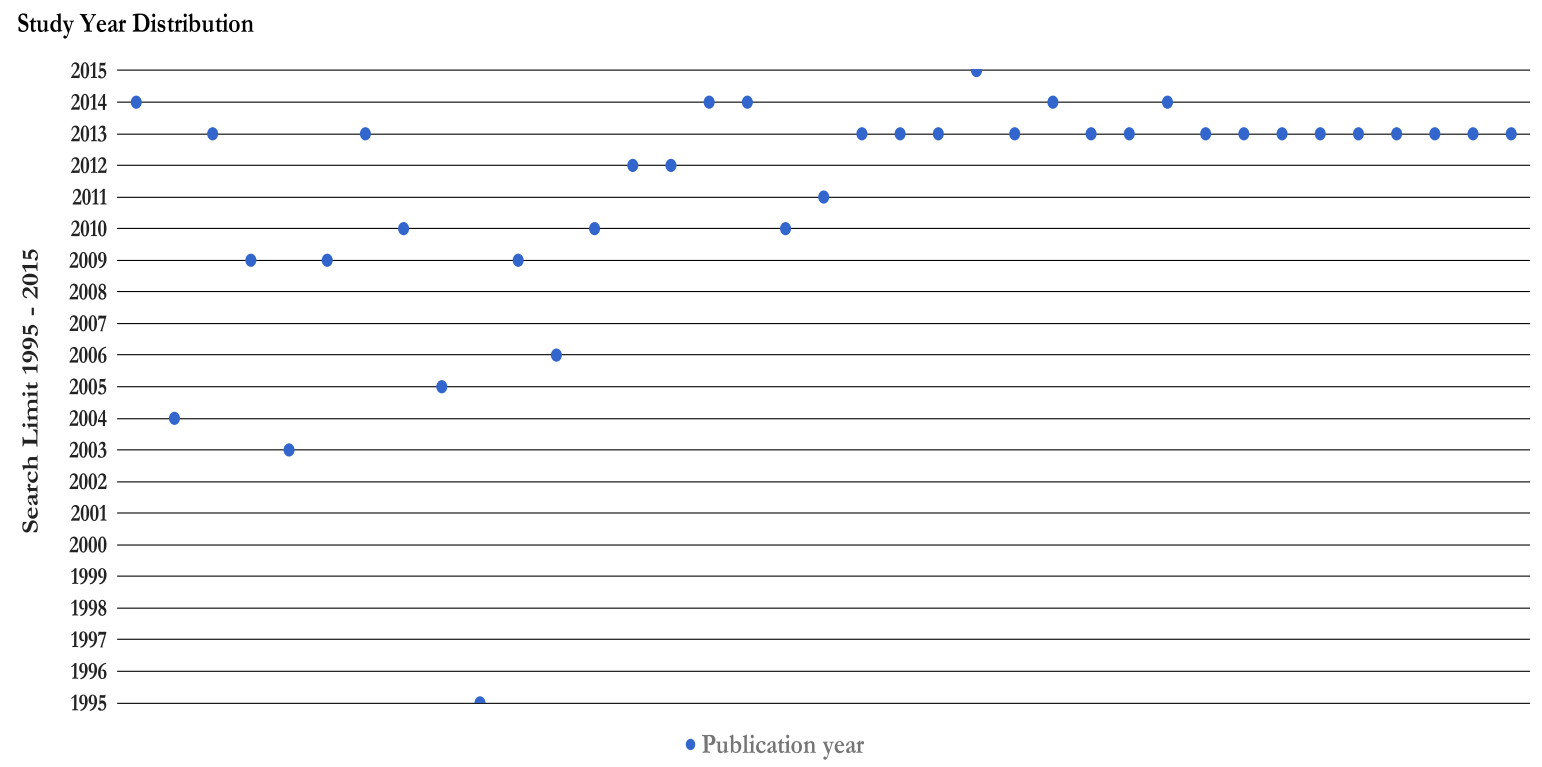

Figure 4: Study publication date distributed

In most cases each paper identified the country where the data were gathered. If this was not the case, like with Yardley et al. (2009), the country was coded as the country in which the first author's institution was located. In total the selected papers gathered data from 25 countries.

The United States was the most represented single country from which data were collected with five studies, followed by Australia (3) and South Africa (3). Europe (Including the UK) was well represented with 24 studies, followed by the Far East with three studies. The large number of studies from Europe was due to the project Impact of Policies for Plagiarism in Higher Education Across Europe (IPPHEAE).

Partly funded by the European Union under the Erasmus Lifelong Learning Programme, IPPHEAE set out to "compare and evaluate the different approaches to plagiarism and academic misconduct" between twenty-seven EU countries (IPPHEAE, 2013). In total IPPHEAE (2013) produced twentyseven reports, each focusing on a single EU country. Of the 27 reports, those from the Netherlands, Belgium, Hungary, Italy, Latvia, Denmark, Luxembourg, and Sweden were not included due to a low response rate (Demoliou, 2013; Glendinning, 2014; Glendinning et al., 2013a, 2013c, 2013d; 
Glendinning \& Orim, 2015; Jóźwik et al., 2013; Stabingis et al., 2014). As far as Africa is concerned, other than papers from South Africa, only papers from Botswana and Zambia were evaluated.

In almost all the cases data were collected, aggregated, and summarised by means of a survey. The only exception being the paper by Doró (2014), who in the author's own words used an exploratory investigation that asked students to write a short opinion essay on why they plagiarise. The opinion essay was then subsequently analysed for the reasons provided.

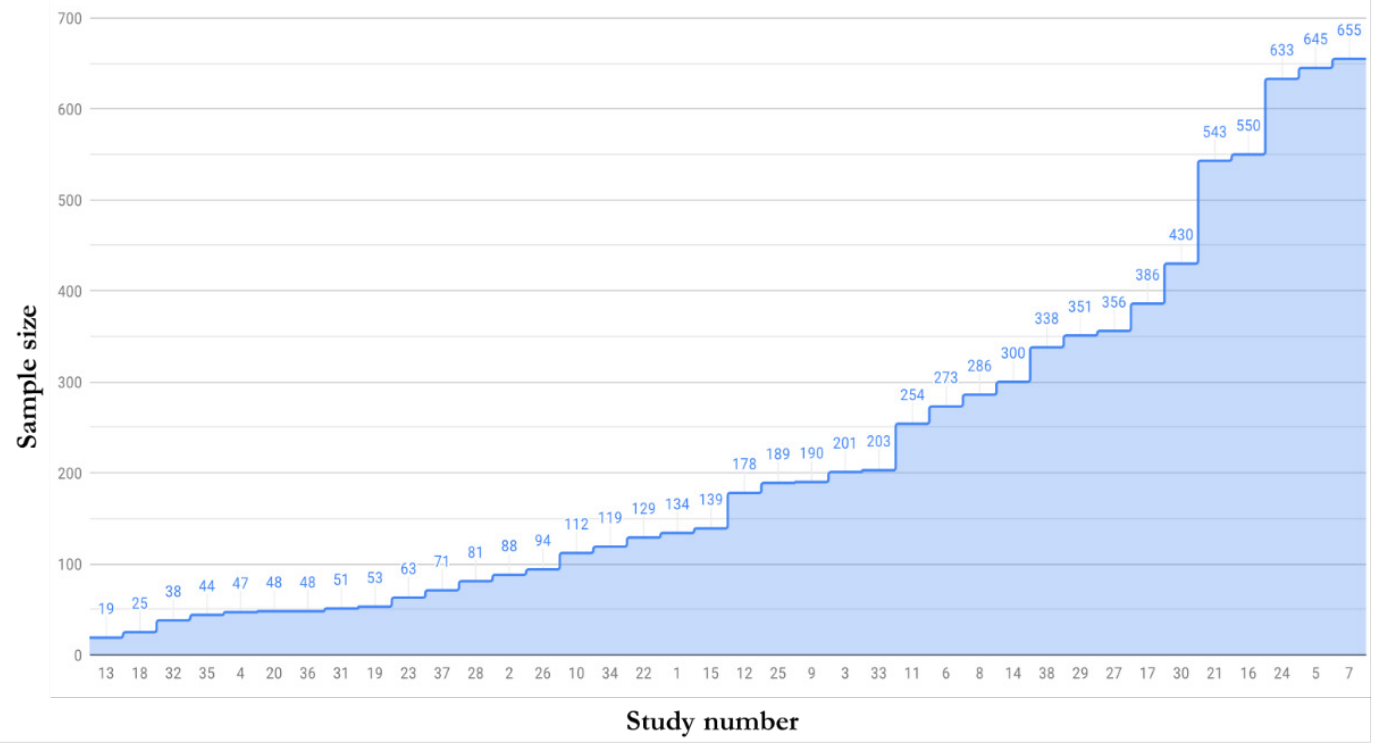

Figure 5: Sample size across all selected studies

The total sample size across all studies for all students, were eight thousand three hundred and sixtyfour respondents with a mean sample size of two hundred and twenty per study $(\mathrm{SD}=189)$. The biggest sample as depicted in Figure 5, was that of E.-J. Park et al. (2013) ( $\mathrm{n}=655)$, while the study with the smallest sample overall was the one from Mooko and Robinson (1999) ( $\mathrm{n}=19)$. Mooko and Robinson (1999) sampled exclusively from university faculty members in their survey. The study with the smallest sample of student responses was that of Doró (2014) $(n=25)$. All studies, except the one of Mooko and Robinson (1999), sampled either students exclusively or both students and faculty members. The only other exception was the reports produced as part of the Impact of Policies for Plagiarism in the Higher Education Across Europe (IPPHEAE) project that included responses from university students, faculty members, organisations, and institutions. The results from organizations and institutions were not included in the summary presented here. The data gathered by each study were further extracted and evaluated.

\section{SYNTHESIS OF COLLECTED DATA}

For each paper evaluated two sets of results were extracted if available. The first set of results contained the ranked reasons that may lead to plagiarism according to students. The second set of results listed the ranked reasons that may lead to plagiarism according to faculty members. All but one paper presented reasons for plagiarism according to students. Seventeen studies presented both the students and faculty members' reasons.

In keeping with the purpose of the systematic review, to identify why students choose to plagiarise and develop metrics that will align with these reasons, in going forward with the current research, only the reasons for plagiarising from the students' perspective were synthesised. This disqualified the paper by Mooko and Robinson (1999) from this phase of the review. 
To synthesize and interpret the data in the selected papers, the different reasons presented by each paper needed to be categorized to find commonality for comparison.

\section{Categorization and coding of different reasons for plagiarism}

As the studies under review not part of the IPPHEAE project used different terminology to describe reasons for plagiarism, it was decided to code and categorise the ranked reasons for plagiarism as presented by each study into a predefined category and then average the position of the category across the different studies.

A typology of plagiarism reasons fine grained enough to accommodate the various reasons presented by the different papers evaluated in this systematic review, was presented by C. Park (2003) after reviewing the work of Stevens and Stevens, Davis et al., and Straw. C. Park (2003) presented nine possible reasons for plagiarism, namely, a genuine lack of understanding, efficiency gain, bad time management, personal values or attitudes, defiance, students' attitudes towards teachers and class, denial or neutralisation, temptation and opportunity and lack of deterrence. It was deemed necessary by the authors of this work to add an additional two categories to the original nine to accommodate the wide variety of reasons presented in the papers under review. The additional categories are 'academic difficulties' and 'external values/attitudes. Consequently, for the purpose of this research, the different reasons for students plagiarising collected from the studies under review was coded and categorised as follows.

R-GLU: Genuine lack of understanding. Students may plagiarise because of a lack of understanding or knowledge of the matter at hand or by accident. Ignorance, a lack of proper referencing skills, and unfamiliarity about the ethical considerations applied in research, may also play a role.

Examples of reasons reported in the studies under review subsequently coded as R-GLU, include "Ignorance/inadequate referencing skills" (Dawson, 2004) and "I'm not sure what plagiarism means/I didn't realize I had plagiarized” (Kwong et al., 2010).

R-EG: Efficiency gain. The economy of effort plays a role in this category. Students may plagiarise to get a better grade more quickly. They may also want to save and reduce their workload by plagiarising or attempting to use plagiarism to make the assignment easier, thereby improving their grades. A student may furthermore be retaking a prescribed class or course and may just want to pass it with little regard to learning from the content. In addition, efficiency gain may be linked to the future expected monetary reward that students believe comes with a obtaining a higher-grade average.

Examples of reasons reported in the studies under review subsequently coded as R-EG, include "Want to get a better job in the future" (E.-J. Park et al., 2013) and "To increase the mark" (Franklyn-Stokes \& Newstead, 1995).

R-BTM: Bad time management. Plagiarism also occurs because of time pressures. Turning to plagiarism due to a lack of time could be a result of the student taking too many classes, extracurricular activities, or working a part-time job. Sometimes students would try to complete the assignment but find that their time is running out, or that the assignment due date coincides with that of other assignments. Students could therefore turn to plagiarism. Losing time because of laziness or procrastination is an additional time management factor that could lead to plagiarism.

Examples of reasons reported in the studies under review subsequently coded as R-BTM, include "Laziness or bad time management" (Wilkinson, 2009) and "The limited time they have to study" (Theart \& Smit, 2012).

R-PVA: Personal values/attitudes. Plagiarism could also take place because of personal crises, circumstances, values, or attitudes. Students may plagiarise due to a fear of failure or conversely because they regard plagiarising as a challenge with the associated satisfaction that can be gained if not caught. Some students may furthermore believe that it is not unethical to plagiarise. Self-confidence 
or a lack of it may also play a role as students may believe their own writing is not good enough to meet the demands.

Examples of reasons reported in the studies under review subsequently coded as R-PVA, include "Wanted to see if would get caught plagiarizing" (Vogts, 2009) and "Fear of failure" (Dawson, 2004).

R-D: Defiance. Defiance towards accepted institutional procedures or social rules regarding plagiarism or a complete lack of self-motivation may lead to plagiarism taking place. In turning to plagiarism, students may show a lack of respect for authority or attempt to rebel against authority. They may also show defiance in how they regard the importance or the value of the work they are required to complete. A disinterest in the task or a negative attitude towards assignments and tests may also play a role.

Examples of reasons reported in the studies under review subsequently coded as R-D, include "Felt the assignment was of no educational value" (Henning et al., 2014) and "Did not need to learn the topic" (Akakandelwa \& Sitali, 2010)

R-SATC: Students' attitudes towards teachers and class. Plagiarism may also result from a negative attitude towards the teacher, class, content, or the way content is presented. Students may believe the instructor (teacher) does not care if students plagiarise or may not bother to check their work for plagiarism. In addition to not liking the lecturer, the student may also believe the lecturer's expectations for the class are unfair or too high. They may, moreover, feel that the instructor failed to explain all the rules and requirements clearly in class.

Examples of reasons reported in the studies under review subsequently coded as R-SATC, include "Due to the knowledge or feeling that the lecturer to whom the assignment is to be submitted does not thoroughly read the assignments" (Comas-Forgas \& Sureda-Negre, 2010) and "No big deal; does not matter to professor" (D. Jones, 2011)

R-DN: Denial or neutralisation. Legitimising behaviour by means of denial or by passing the blame to others could be a reason for plagiarism. Students may claim they have "always done it like that" or that all their peers plagiarise anyway. When cheating is involved, they may legitimise behaviour by saying they were not adequately prepared. Students would often not see anything wrong with plagiarism as they believe it is a victimless crime and they are not hurting anyone.

Examples of reasons reported in the studies under review subsequently coded as R-DN, include "Everyone does Internet plagiarism" (Eret \& Ok, 2014) or "Because others do it" (Russikoff et al., 2003).

R-TO: Temptation and opportunity. Easy access to information sources and the availability of opportunities could make it tempting for students to plagiarise. A large amount of information is freely accessible via the Internet and other sources. The opportunity may also exist for students to hire others to complete their assignments.

Examples of reasons reported in the studies under review subsequently coded as R-TO, include "It is easy to cut and paste from the Internet" (Glendinning et al., 2013b) and "It was easy - the temptation was too great" (Brimble \& Stevenson-Clarke, 2005).

R-LD: Lack of deterrence. The perceived benefit resulting from plagiarism outweighs the risk of punishment due to a low chance of getting caught and non-severe consequences if ever caught. Students may also not be aware of penalties if caught.

Examples of reasons reported in the studies under review subsequently coded as R-LD, include "Permissive plagiarism practice" (Doró, 2014) and "I hadn't heard of other students being penalised before" (Brimble \& Stevenson-Clarke, 2005).

R-AD Academic difficulties. Various academic deficiencies leading to plagiarism were found. Students may have a difficulty with the topic under study or feel the task is far beyond their academic 
comprehension and ability. The lack of language ability and comprehension may also be a reason for plagiarising.

Examples of reasons reported in the studies under review subsequently coded as R-AD, include "Did not understand the assignment" (Sentleng, 2010) and "They feel the task is completely beyond their ability" (Foltynek, 2013).

R-EVA: External values / attitudes. Plagiarism could result because of external influences or inter-personal relationships. Students may often be under external pressure to succeed due to high expectations and pressure exerted by family members or as a requirement of a scholarship. On an interpersonal level a student may cheat to maintain a good relationship with their peers or because of peer pressure to share their work. Examples of reasons reported in the studies under review subsequently coded as R-EVA, include "They feel external pressure to succeed" (Glendinning et al., 2013e) and "Family pressure to succeed" (Henning et al., 2014).

The ranked reasons for plagiarism according to each individual study under review were coded and combined into a single dataset for further analysis and reporting.

\section{INTERPRETATION OF SYNTHESISED STUDIES}

Conducting Step 4 of the selected systematic research methodology resulted in a single dataset that contains the categorised ranked reasons for plagiarism for each of the selected studies under review. By using this dataset, Figure 6 was generated indicating the average position (1 most likely, 11 least likely) for each reason across the selected studies, as ranked by students.

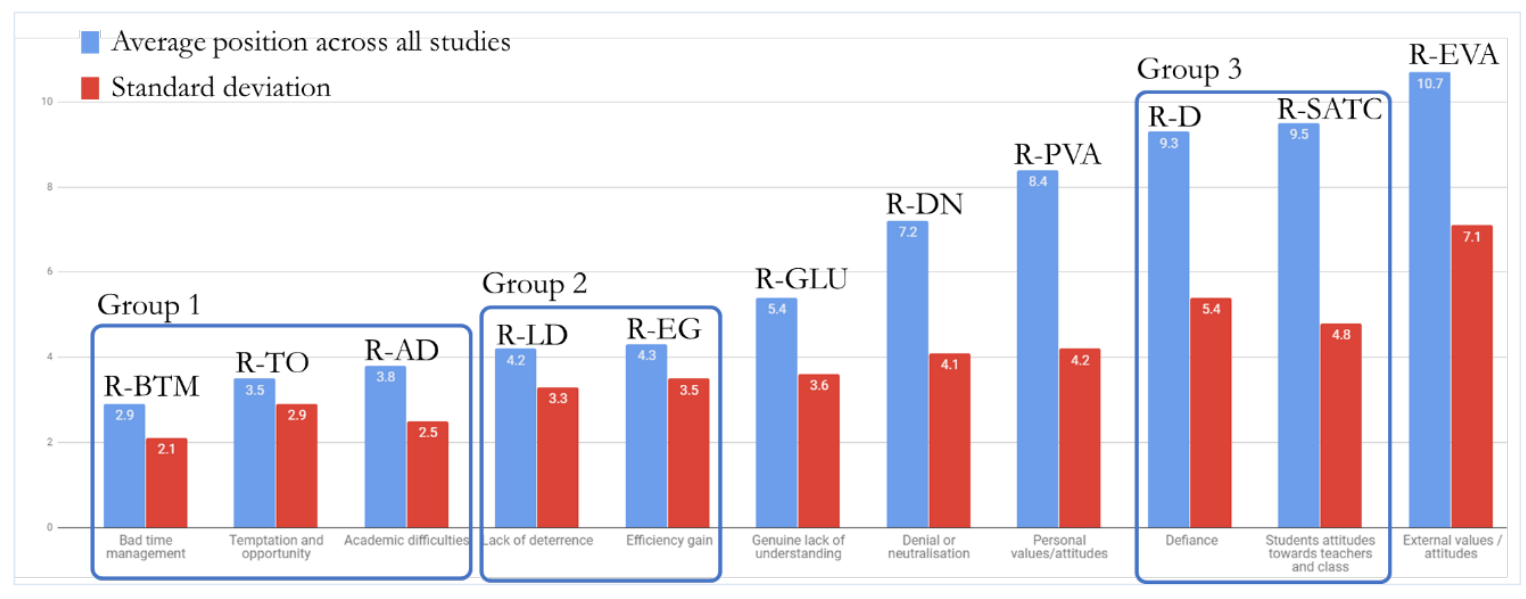

Figure 6: Synthesised and categorised data indicating the average position for plagiarism reasons across thirty-seven studies

As portrayed in Figure 6, the different study respondents on average ranked 'Bad time management' as the most likely reason leading to the decision to plagiarise, closely followed by 'Temptation and opportunity', and 'Academic difficulties'. The three reasons may be grouped closely (group 1 in Figure 6) as one of them may aid the likelihood of the others being the actual reason for plagiarism. It may start with bad time management in the form of procrastination or extracurricular activities on the student's side, as the student is not spending enough time on his or her studies, academic difficulties may arise. To mitigate the academic difficulties the student may be tempted to plagiarise.

'Lack of deterrence' and 'Efficiency gain' followed the first group and was ranked similarly in terms of likelihood (group 2 in Figure 6). The reason for the similar ranking in likelihood may have to do with risk and reward behaviour. The student may decide to plagiarise due to possible efficiency gain outweighing the deterrence measures. 
Becoming a less likely reason for plagiarising is 'Genuine lack of understanding' followed by 'Denial or neutralization' and 'Personal values/attitudes'.

On the less likely side 'Defiance' and 'Student attitudes towards teacher and class' were again ranked similarly (group 3 in Figure 6). The teacher, how the class is presented, and teaching and learning methods used may contribute to defiant behaviour together leading to plagiarism.

The lowest ranking reason for plagiarism consisted of external values and attitudes. This would suggest that students are less likely to plagiarise due to external pressure from parents, the school, or their peers.

\section{CONCLUSION}

Using a systematic review methodology, the information in thirty-seven studies was used to find the factors that will influence students' decisions to plagiarise.

To normalise the data gathered from the different studies, several categories that were fine grained enough to accommodate the various reasons presented were identified. The categories included a genuine lack of understanding, efficiency gain, time management, personal values or attitudes, defiance, student attitude towards teacher and class, denial or neutralisation, temptation and opportunity, lack of deterrence, academic difficulties, and external values or attitudes.

When the ranked reasons from the individual studies under review were combined, it was discovered that both the individual IPPHEAE studies and the rest of the studies mostly agreed about the top reasons that influenced students to plagiarise. The top reasons why according to students, they plagiarise were because of -

- temptation and easy opportunity;

- a lack of deterrence;

- bad time management;

- academic difficulty; and

- expected gain in efficiency when plagiarising.

It would thus indicate that students would consider plagiarism when running out of time. As they realise they will not complete the work in time, they may investigate other avenues and be tempted by easy access to information to plagiarise from it to meet a deadline.

Time pressures and the temptation to plagiarise may be compounded by academic difficulties or language and comprehension problems. As these pressures start to increase, the perceived lack of deterrence comes into play. The student may believe the chances of getting caught are low or the penalties if caught are not severe enough to outweigh the efficiency gain expected from plagiarising.

\section{REFERENCES}

Aasheim, C. L., Rutner, P. S., Lixin Li, \& Williams, S. R. (2012). Plagiarism and programming: A survey of student attitudes. Journal of Information Systems Education, 23(3), 297-313. http://search.ebscohost.com/login.aspx?direct=true\&db=lxh\&AN=85803511\&site=ehost-live

Akakandelwa, A., \& Sitali, W. (2010). A survey of humanities and social science students' attitudes towards plagiarism. Zambia Library Association Journal, 25(1-2), 95-113. http://journals.co.za/content/zambia/25/1-2/AJA0049853X_520?fromSearch=true

Alderson, P., Green, S., \& Higgins, J. (Eds.). (2004). Cochrane reviewers' handbook 4.2.2. John Wiley \& Sons. https://www.iecs.org.ar/cochrane/guias/Handbook 4-2-2.pdf

Austin, M. J., \& Brown, L. D. (1999). Internet plagiarism: Developing strategies to curb student academic dishonesty. The Internet and Higher Education, 2(1), 21-33. https://doi.org/10.1016/S1096-7516(99)00004-4 
Bachore, M. M. (2015). Vicious circle of plagiarism in the academic world: The treat for the quality of education. International Journal of Current Advanced Research, 4(2), 12-16. http://journalijcar.org/sites/default/files/issue-files/4.pdf

Bamford, J., \& Sergiou, K. (2005). International students and plagiarism: An analysis of the reasons for plagiarism among international foundation students. Investigations in University Teaching and Learning, 2(2), 17-22. http://eprints.londonmet.ac.uk/173/

Baruchson-Arbib, S., \& Yaari, E. (2004). Printed versus Internet plagiarism: A study of students' perception. International Journal of Information Ethics, 1(6), 29-35. http://container.zkm.de/ijie/ijie/no001/ijie 001 full.pdf\#page=29

Belter, R. W., \& du Pré, A. (2009). A strategy to reduce plagiarism in an undergraduate course. Teaching of Psychology, 36(4), 257-261. https://doi.org/10.1080/00986280903173165

Betts, L. R., Bostock, S. J., Elder, T. J., \& Trueman, M. (2012). Encouraging good writing practice in first-year psychology students: An intervention using Turnitin. Psychology Teaching Review, 18(2), 74-81. http://eric.ed.gov/?id=EJ991412

Bing, M. N., Davison, H. K., Vitell, S. J., Ammeter, A. P., Garner, B. L., \& Novicevic, M. M. (2012). An experimental investigation of an interactive model of academic cheating among business school students. Academy of Management Learning \& Education, 11(1), 28-48. https://doi.org/10.5465/amle.2010.0057

Bretag, T., Mahmud, S., Wallace, M., Walker, R., McGowan, U., East, J., Green, M., Partridge, L., \& James, C. (2014). 'Teach us how to do it properly!' An Australian academic integrity student survey. Studies in Higher Education, 39(7), 1150-1169. https://doi.org/10.1080/03075079.2013.777406

Briggs, R. (2003). Shameless! Reconceiving the problem of plagiarism. Australian Universities Review, 46(1), 19_ 23. https:// search.informit.com.au/documentSummary; $\mathrm{dn}=921535952454436$;res=IELHSS

Brimble, M., \& Stevenson-Clarke, P. (2005). Perceptions of the prevalence and seriousness of academic dishonesty in Australian universities. The Australian Educational Researcher. http://link.springer.com/article/10.1007/BF03216825

Briner, R. B., \& Denyer, D. (2012). Systematic review and evidence synthesis as a practice and scholarship tool. Handbook of evidence-based management: companies, classrooms and research, 112-129. http://www.cebma.info/wpcontent/uploads/Briner-Denyer-Systematic-Review-Evidence-Synthesis.pdf

Briner, R. B., Denyer, D., \& Rousseau, D. M. (2009). Evidence-based management: Concept cleanup time? The Academy of Management Perspectives, 23(4), 19-32. http://amp.aom.org/content/23/4/19.abstract

Carr, R. (2006). What users want: An academic hybrid library perspective. Ariadne, 46. http://www.ariadne.ac.uk/issue46/carr?utm medium=twitter\&utm source=twitterfeed

Chao, C.-A., Wilhelm, W. J., \& Neureuther, B. D. (2009). A study of electronic detection and pedagogical approaches for reducing plagiarism. The Journal of Research in Business Education, 51(1), 31. http://www.questia.com/library/journal/1P3-1850902091/a-study-of-electronic-detection-andpedagogical-approaches

Clegg, S., \& Flint, A. (2006). More heat than light: Plagiarism in its appearing. British Journal of Sociology of Education, 27(3), 373-387. https://doi.org/10.1080/01425690600750585

Comas-Forgas, R., \& Sureda-Negre, J. (2010). Academic plagiarism: Explanatory Factors from Students' Perspective. Journal of Academic Ethics, 8(3), 217-232. https://doi.org/10.1007/s10805-010-9121-0

Conradson, S., \& Hernández-Ramos, P. (2004). Computers, the internet, and cheating among secondary school students: Some implications for educators. Practical Assessment, Research \& Evaluation, 9(9), 1-8. http://pareonline.net/getvn.asp?v $=9 \& n=9$

Coren, A. (2011). Turning a blind eye: Faculty who ignore student cheating. Journal of Academic Ethics, 9(4), 291. https://doi.org/10.1007/s10805-011-9147-y

Coyne, S. M., \& Thomas, T. J. (2008). Psychopathy, aggression, and cheating behavior: A test of the CheaterHawk hypothesis. Personality and Individual Differences, 44(5), 1105-1115.

https://doi.org/10.1016/j.paid.2007.11.002 
Cronin, P., Ryan, F., \& Coughlan, M. (2008). Undertaking a literature review: A step-by-step approach. The British Journal of Nursing, 17(1), 38-43. https://doi.org/10.12968/bjon.2008.17.1.28059

Das, N., \& Panjabi, M. (2011). Plagiarism: Why is it such a big issue for medical writers? Perspectives in Clinical Research, 2(2), 67-71. https://doi.org/10.4103/2229-3485.80370

Dawson, J. (2004). Plagiarism: What's really going on. Seeking Educational Excellence. Proceedings of the 13th Annual Teaching Learning Forum. 13th Annual Teaching Learning Forum, Perth: Murdoch University. http://ctl.curtin.edu.au/events/conferences/tlf/tlf2004/dawson.html

Demoliou, D. (2013). Plagiarism policies in Italy (No. 510321-LLP-1-2010-1-UK-ERASMUS-EMHE). European Union under Erasmus, Lifelong Learning Programme. http://plagiarism.cz/ippheae/files/D2-315\%20IT\%20IPPHEAE $\% 20$ CD $\% 20$ Survey $\% 20$ Italy $\% 20$ Narrative.pdf

Devlin, M., \& Gray, K. (2007). In their own words: A qualitative study of the reasons Australian university students plagiarize. Higher Education Research \& Development, 26(2), 181-198. https://doi.org/10.1080/07294360701310805

Dhillon, J. K., \& Gill, N. C. (2014). Deciphering the system of a systematic review. Dental Research Journal, 11(5), 531-536. https://www.ncbi.nlm.nih.gov/pubmed/25426141

Doró, K. (2014). Why do students plagiarize? EFL Undergraduates' views on the reasons behind plagiarism. Romanian Journal of English Studies, 11(1), 255-263. https://doi.org/10.2478/ries-2014-0029

East, J. (2009). Judging plagiarism: A problem of morality and convention. Higher Education, 59(1), 69-83. https://doi.org/10.1007/s10734-009-9234-9

Easterbrook, S., Singer, J., Storey, M.-A., \& Damian, D. (2008). Selecting empirical methods for software engineering research. In F. Shull, J. Singer, \& D. I. K. Sjøberg (Eds.), Guide to advanced empirical software engineering (pp. 285-311). Springer London. https://doi.org/10.1007/978-1-84800-044-5 11

Ercegovac, Z. (2005). What students say they know, feel, and do about cyber-plagiarism and academic dishonesty? A case study. Proceedings of the American Society for Information Science and Technology, 42(1). http://onlinelibrary.wiley.com/doi/10.1002/meet.1450420142/full

Eret, E., \& Ok, A. (2014). Internet plagiarism in higher education: Tendencies, triggering factors and reasons among teacher candidates. Assessment \& Evaluation in Higher Education, 39(8), 1002-1016. https://doi.org/10.1080/02602938.2014.880776

Etter, S., Cramer, J. J., \& Finn, S. (2006). Origins of academic dishonesty: Ethical orientations and personality factors associated with attitudes about cheating with information technology. Journal of Research on Technology in Education, 39(2), 133-155. http://www.tandfonline.com/doi/abs/10.1080/15391523.2006.10782477

Evans, D., \& Pearson, A. (2001). Systematic reviews of qualitative research. Clinical Effectiveness in Nursing, 5(3), 111-119. https://doi.org/10.1054/cein.2001.0219

Evans, R. (2006). Evaluating an electronic plagiarism detection service: The importance of trust and the difficulty of proving students don't cheat. Active Learning in Higher Education, 7(1), 87-99. https://doi.org/10.1177/1469787406061150

Ferrari, J. R. (2005). Impostor tendencies and academic dishonesty: Do they cheat their way to success? Social Behavior and Personality: An International Journal, 33(1), 11-18. https://doi.org/10.2224/sbp.2005.33.1.11

Flint, A. (2005). Emotion, practice, and plagiarism: exploring the staff perspective. 1-11. https://www.researchgate.net/profile/Sue Clegg3/publication/237698118 Emotion practise and plagia rism exploring the staff perspective/links/00b7d52cb15a5f2846000000.pdf

Flint, A., Macdonald, R., \& Clegg, S. (2005). Emotion, practice, and plagiarism: exploring the staff perspective. In Plagiarism: Prevention, Practice and Policy Conference (pp. 65-72). Northumbria University Press Newcastle. https://www.researchgate.net/publication/237698118 Emotion practise and plagiarism exploring the staff perspective

Flowerdew, J., \& Li, Y. (2007). Plagiarism and second language writing in an electronic age. Annual Review of Applied Linguistics, 27, 161-183. https://doi.org/10.1017/S0267190508070086 
Foltynek, T. (2013). Plagiarism Policies in the Czech Republic (No. 510321-LLP-1-2010-1-UK-ERASMUS-EMHE). European Union under Erasmus, Lifelong Learning Programme. http://plagiarism.cz/ippheae/files/D23-05\%20CZ\%20IPPHEAE $\% 20$ MENDELU $\% 20$ Survey $\% 20$ CzechNarrative $\% 20$ FINAL.pdf

Franklyn-Stokes, A., \& Newstead, S. E. (1995). Undergraduate cheating: Who does what and why? Studies in Higher Education, 20(2), 159-172. https://doi.org/10.1080/03075079512331381673

Ganguly, D., Jones, G. J. F., Ramírez-de-la-Cruz, A., Ramírez-de-la-Rosa, G., \& Villatoro-Tello, E. (2018). Retrieving and classifying instances of source code plagiarism. Information Retrieval Journal, 21(1), 1-23. https://doi.org/10.1007/s10791-017-9313-y

Gerhardt, D. R. (2006). Plagiarism in cyberspace: Learning the rules of recycling content with a view towards nurturing academic trust in an electronic world. UNC Legal Studies Research Paper. http://papers.ssrn.com/sol3/papers.cfm?abstract id=1932386

Glendinning, I. (2014). Plagiarism Policies in the Netherlands (No. 510321-LLP-1-2010-1-UK-ERASMUS-EMHE). European Union under Erasmus, Lifelong Learning Programme. http://plagiarism.cz/ippheae/files/D23-20\%20NL $\% 20$ IPPHEAE $\% 20$ Survey $\% 20$ Holland $\% 20$ Narrative.pdf

Glendinning, I., Michalska. A., \& Orim, S.-M. (2013a). Plagiarism Policies in Belgium (No. 510321-LLP-1-2010-1UK-ERASMUS-EMHE). European Union under Erasmus, Lifelong Learning Programme. http://plagiarism.cz/ippheae/ files/D2-302\%20BE $\% 20$ RT $\% 20$ IPPHEAE $\% 20$ CU $\% 20$ Survey $\% 20$ BelgiumNarrative.pdf

Glendinning, I., Michalska. A., \& Orim, S.-M. (2013b). Plagiarism Policies in Finland. http://plagiarism.cz/ippheae/files/D2-310\%20FI $\% 20$ RT $\% 20$ IPPHEAE $\% 20$ CU $\% 20$ Survey $\% 20$ FinlandNarrative.pdf

Glendinning, I., Michalska, A., \& Orim, S.-M. (2013c). Plagiarism Policies in Hungary (No. 510321-LLP-1-2010-1UK-ERASMUS-EMHE). European Union under Erasmus, Lifelong Learning Programme. http://plagiarism.cz/ippheae/files/D2-313\%20HU $\% 20$ RT $\% 20$ IPPHEAE $\% 20$ CU\%20Survey $\% 20$ HungaryNarrative.pdf

Glendinning, I., Michalska, A., \& Orim, S.-M. (2013d). Plagiarism Policies in Luxembourg (No. 510321-LLP-12010-1-UK-ERASMUS-EMHE). European Union under Erasmus, Lifelong Learning Programme. http://plagiarism.cz/ippheae/files/D2-317\%20LU $\% 20$ RT $\% 20$ IPPHEAE $\% 20$ CU $\% 20$ Survey $\% 20$ LuxembourgNarrative.pdf

Glendinning, I., Michalska, A., \& Orim, S.-M. (2013e). Plagiarism Policies in the United Kingdom (No. 510321-LLP1-2010-1-UK-ERASMUS-EMHE). European Union under Erasmus, Lifelong Learning Programme. http://plagiarism.cz/ippheae/files/D2-327\%20UK\%20RT $\% 20$ IPPHEAE $\% 20$ CU $\% 20$ Survey $\% 20 U K N a r r a t i v e O c t 2013 . p d f$

Glendinning, I., \& Orim, S. M. (2015). Plagiarism Policies in Sweden (No. 510321-LLP-1-2010-1-UK-ERASMUSEMHE). European Union under Erasmus, Lifelong Learning Programme. http://plagiarism.cz/ippheae/files/D2-324\%20SE $\% 20$ RT $\% 20$ IPPHEAE $\% 20$ CU $\% 20$ Survey $\% 20$ SwedenNarrative.pdf

Graham-Matheson, L., \& Starr, S. (2013). Is it cheating-or learning the craft of writing? Using Turnitin to help students avoid plagiarism. Research in Learning Technology, 21(1), 1-13. http://www.researchinlearningtechnology.net/index.php/rlt/article/view/17218

Grijalva, T. C., Nowell, C., \& Kerkvliet, J. (2006). Academic honesty and online courses. College Student Journal, 40(1), 180-185. http://search.proquest.com/openview/8d7b71638ea6157334a3b2fc73d967c0/1?pqorigsite $=$ gscholar

Harris, R. (2002). Anti-plagiarism strategies for research papers. Virtual Salt. http://students.umw.edu/chls/files/2012/10/Anti-Plagiarism-Strategies1.pdf

Hart, C. (2018). Doing a literature review: Releasing the research imagination. SAGE. https://play.google.com/store/books/details?id=ff1BDwAAQBAJ

Hart, M., \& Friesner, T. (2004). Plagiarism and poor academic practice-A threat to the extension of e-learning in higher education? Electronic Journal on E-Learning, 2(1), 89-96. http://ancasta.net/pubs/papers/ppap.pdf 
Haskins, B., \& Pieterse, V. (2016). Lessons learnt in applying automated code plagiarism detection in an introductory programming module. The Independent Journal of Teaching and Learning, 11(1), 69-81. https://journals.co.za/content/jitl1/11/1/EJC195346

Hayes, N. (2003). Alienation and plagiarism: Coping with otherness in our assessment practice. http://eprints.lancs.ac.uk/48693/

Helgesson, G., \& Eriksson, S. (2015). Plagiarism in research. Medicine, Health Care, and Philosophy, 18(1), 91-101. https://doi.org/10.1007/s11019-014-9583-8

Henning, M. A., Ram, S., Malpas, P., Sisley, R., Thompson, A., \& Hawken, S. J. (2014). Reasons for academic honesty and dishonesty with solutions: A study of pharmacy and medical students in New Zealand. Journal of Medical Ethics, 40(10), 702-709. https://doi.org/10.1136/medethics-2013-101420

Howard, R. M. (1995). Plagiarisms, authorships, and the academic death penalty. College English, 57(7), 788-806. https://doi.org/10.2307/378403

Howell, S. L., Sorensen, D., \& Tippets, H. R. (2009). The new (and old) news about cheating for distance educators. Online Journal of Distance Learning Administration, 12(3). http://www.westga.edu/ distance/ojdla/fall123/howell123.html

IPPHEAE. (2013). Impact of Policies for Plagiarism in Higher Education Across Europe (IPPHEAE). http://plagiarism.cz/ippheae/

Jackson, C. J., Levine, S. Z., Furnham, A., \& Burr, N. (2002). Predictors of cheating behavior at a university: A lesson from the psychology of work. Journal of Applied Social Psychology, 32(5), 1031-1046. https://doi.org/10.1111/i.1559-1816.2002.tb00254.x

Jones, D. (2011). Academic dishonesty: Are more students cheating? Business Communication Quarterly. http://faculty.mwsu.edu/psychology/dave.carlston/Writing\%20in\%20Psychology/Academic\%20Dishon esty/new/adprev.pdf

Jones, M., \& Sheridan, L. (2014). Back translation: An emerging sophisticated cyber strategy to subvert advances in 'digital age' plagiarism detection and prevention. Assessment \& Evaluation in Higher Education, 40(5), 712-724. https://doi.org/10.1080/02602938.2014.950553

Jóźwwik, K., Glendinning, I., \& Michałowska-Dutkiewicz, A. (2013). Plagiarism policies in Denmark (No. 510321 LLP-1-2010-1-UK-ERASMUS-EMHE). European Union under Erasmus, Lifelong Learning Programme. http://plagiarism.cz/ippheae/files/D2-3-07\%20DK\%20IPPHEAE_Survey\%20DenmarkNarrative.pdf

Khan, K. S., Kunz, R., Kleijnen, J., \& Antes, G. (2003). Five steps to conducting a systematic review. Journal of the Royal Society of Medicine, 96(3), 118-121. http://www.ncbi.nlm.nih.gov/pubmed/12612111

Kiehl, E. M. (2006). Using an ethical decision-making model to determine consequences for student plagiarism. The Journal of Nursing Education, 45(6), 199-203. http://www.ncbi.nlm.nih.gov/pubmed/16780007

Kitchenham, B., \& Charters, S. (2007). Guidelines for performing systematic literature reviews in software engineering (EBSE-2007-01). Keele University.

https://www.cs.auckland.ac.nz/ norsaremah/2007\%20Guidelines $\% 20$ for $\% 20$ performing $\% 20$ SLR $\% 20$ in \%20SE $\% 20 \mathrm{v} 2.3 . \mathrm{pdf}$

Kwong, T., Ng, H., Mark, K., \& Wong, E. (2010). Students' and faculty's perception of academic integrity in Hong Kong. Campus-Wide Information Systems, 27(5), 341-355. https://doi.org/10.1108/10650741011087766

Lancaster, T., \& Culwin, F. (2004). A comparison of source code plagiarism detection engines. Computer Science Education, 14(2), 101-112. https://doi.org/10.1080/08993400412331363843

LaSalle, R. E. (2009). The perception of detection, severity of punishment and the probability of cheating. Journal of Forensic Studies in Accounting \& Business, 1(2).

Lawson, R. A. (2004). Is classroom cheating related to business students' propensity to cheat in the real world? Journal of Business Etbics: JBE, 49(189), 189-199. http://link.springer.com/article/10.1023/B:BUSI.0000015784.34148.cb 
Ledwith, A., \& Rísquez, A. (2008). Using anti-plagiarism software to promote academic honesty in the context of peer reviewed assignments. Studies in Higher Education, 33(4), 371-384. https://doi.org/10.1080/03075070802211562

Li, Y., \& Casanave, C. P. (2012). Two first-year students' strategies for writing from sources: Patchwriting or plagiarism? Journal of Second Language Writing, 21, 165-180. http://www.sciencedirect.com/science/article/pii/S1060374312000197

Lim, V. K. G., \& See, S. K. B. (2001). Attitudes toward, and intentions to report, academic cheating among students in Singapore. Ethics \& Behavior, 11(3), 261-274. https://doi.org/10.1207/S15327019EB1103 5

Louw, D., \& Pieterse, V. (2015). Dealing with plagiarism in introductory programming. In Proceedings of the International Conference on Computer Science Education Innovation \& Technology (CSEIT) (Vol. 4) 4-13. https://dl4.globalstf.org/products-page/proceedings/cseit/dealing-with-plagiarism-in-introductoryprogramming/

Love, P. G., \& Simmons, J. (1998). Factors influencing cheating and plagiarism among graduate students in a college of education. College Student Journal, 32(4), 539-550. http://psycnet.apa.org/psycinfo/1998-03231$\underline{007}$

Ma, H., Lu, E. Y., Turner, S., \& Wan, G. (2007). An empirical investigation of digital cheating and plagiarism among middle school students. American Secondary Education, 35(2), 69-82. http://www.jstor.org/stable/41406290

Macdonald, R., \& Carroll, J. (2006). Plagiarism-A complex issue requiring a holistic institutional approach. Assessment \& Evaluation in Higher Education, 31(2), 233-245. https://doi.org/10.1080/02602930500262536

Mallett, R., Hagen-Zanker, J., Slater, R., \& Duvendack, M. (2012). The benefits and challenges of using systematic reviews in international development research. Journal of Development Effectiveness, 4(3), 445-455. https://doi.org/10.1080/19439342.2012.711342

Marshall, S., \& Garry, M. (2005). How well do students really understand plagiarism? Ascilite 2005: Balance, Fidelity, Mobility: Maintaining the Momentum, 457-467. http://www.ascilite.org/conferences/brisbane05/blogs/proceedings/52 Marshall.pdf

Marshall, S., \& Garry, M. (2006). NESB and ESB students' attitudes and perceptions of plagiarism. International Journal for Educational Integrity, 2(1), 26-37. https://doi.org/10.21913/IJEI.v2i1.25

Martin, D. F. (2005). Plagiarism and technology: A tool for coping with plagiarism. Journal of Education for Business, 80(3), 149-152. https://doi.org/10.3200/JOEB.80.3.149-152

McCabe, D. L., \& Stephens, J. M. (2006). Epidemic as opportunity: Internet plagiarism as a lever for cultural change. Teachers College Record.

https://www.researchgate.net/profile/Jason Stephens4/publication/260165435 Epidemic as opportuni ty Internet plagiarism as a lever for cultural change/links/5760712008ae244d0370ce92/Epidemic-asopportunity-Internet-plagiarism-as-a-lever-for-cultural-change.pdf

McCabe, D. L., Trevino, L. K., \& Butterfield, K. D. (2001). Cheating in academic institutions: A decade of research. Ethics \& Behavior, 11(3), 219-232. https://doi.org/10.1207/S15327019EB1103 2

McDowell, L., \& Brown, S. (2001). Assessing students: Cheating and plagiarism. The Higher Education Academy, 112.

Mirshekary, S., \& Lawrence, A. D. K. (2009). Academic and business ethical misconduct and cultural values: A cross national comparison. Journal of Academic Ethics, 7(3), 141-157. https://doi.org/10.1007/s10805-009$\underline{9093-0}$

Mitchell, H. (n.d.). Sabinet African journals. Retrieved May 25, 2020, from https://www.sabinet.co.za/information-services/online-journals/african-journals

Mooko, T., \& Robinson, B. (1999). A survey of University of Botswana academic staff views on student plagiarism. Mosenodi, 7(2), 21-32. http://journals.co.za/content/mosenodi/7/2/AJA1021559X 166

Okoli, C., \& Schabram, K. (2010). A guide to conducting a systematic literature review of information systems research. Sprouts: Working Papers on Information Systems, 10(26), 1-50. http://sprouts.aisnet.org/10-26/ 
Parameswaran, A., \& Devi, P. (2006). Student plagiarism and faculty responsibility in undergraduate engineering labs. Higher Education Research \& Development, 25(3), 263-276. https://doi.org/10.1080/07294360600793036

Park, C. (2003). In OTHER (PEOPLE'S) WORDS: Plagiarism by university students--literature and lessons. Assessment \& Evaluation in Higher Education, 28(5), 471-488. https://doi.org/10.1080/02602930301677

Park, E.-J., Park, S., \& Jang, I.-S. (2013). Academic cheating among nursing students. Nurse Education Today, 33(4), 346-352. https://doi.org/10.1016/j.nedt.2012.12.015

Pecorari, D. (2003). Good and original: Plagiarism and patchwriting in academic second-language writing. Journal of Second Language Writing, 12(4), 317-345. https://doi.org/10.1016/j.jslw.2003.08.004

Portillo-Dominguez, A. O., Ayala-Rivera, V., Murphy, E., \& Murphy, J. (2017). A unified approach to automate the usage of plagiarism detection tools in programming courses. 2017 12th International Conference on Computer Science and Education (ICCSE), 18-23. https://doi.org/10.1109/ICCSE.2017.8085456

Pupovac, V., Bilic-Zulle, L., \& Petrovecki, M. (2008). On academic plagiarism in Europe. An analytical approach based on four studies. Digithum, 10, 13-18. http://www.uoc.edu/digithum/10/dt/eng/pupovac bilic-zulle petrovecki.pdf

Ridley, D. (2012). The literature review: A step-by-step guide for students. SAGE Publications. http://books.google.co.za/books?id=DF-oJOmstfEC

Roig, M. (2001). Plagiarism and paraphrasing criteria of college and university professors. Ethics \& Behavior, 11(3), 307-323. https://doi.org/10.1207/S15327019EB1103 8

Rowe, N. C. (2004). Cheating in online student assessment: Beyond plagiarism. On-Line Journal of Distance Learning Administration, 7(2). http://calhoun.nps.edu/handle/10945/36015

Russikoff, K., Fucaloro, L., \& Salkauskiene, D. (2003). Plagiarism as a cross-cultural phenomenon. The CATESOL Journal. http://www.catesoljournal.org/wp-content/uploads/2014/07/CJ15 russikoff.pdf

Scanlan, C. L. (2006). Strategies to promote a climate of academic integrity and minimize student cheating and plagiarism. Journal of Allied Health, 35(3), 179-185. http://www.ncbi.nlm.nih.gov/pubmed/17036675

Scanlon, P. M., \& Neumann, D. R. (2002). Internet plagiarism among college students. Journal of College Student Development, 43(3), 374-385. http://citeseerx.ist.psu.edu/viewdoc/download?doi=10.1.1.465.268\&rep=rep1\&type=pdf

Sentleng, M. P. (2010). Plagiarism among undergraduate students in the Faculty of Applied Science at a South African bigher education institution. http://etd.uwc.ac.za/xmlui/handle/11394/1936

Sheard, J., \& Dick, M. (2011). Computing student practices of cheating and plagiarism: A decade of change. Proceedings of the 16th Annual Joint Conference on Innovation and Technology in Computer Science Education, 233-237. https://doi.org/10.1145/1999747.1999813

Slobogin, K. (2002). Survey: Many students say cheating's OK. CNN. Com. http://jblackburnmorrow.pbworks.com/w/file/fetch/65310666/RP1Rdg1 Cheating'sOK Slobogin2002.pdf

Smedley, A., Crawford, T., \& Cloete, L. (2015). An intervention aimed at reducing plagiarism in undergraduate nursing students. Nurse Education in Practice, 15(3), 168-173. https://doi.org/10.1016/j.nepr.2014.12.003

Stabingis, L., Šarlauskienè, L., \& Čepaitienè, N. (2014). Plagiarism policies in Latvia (No. 510321-LLP-1-2010-1UK-ERASMUS-EMHE). European Union under Erasmus, Lifelong Learning Programme. http://plagiarism.cz/ippheae/files/D2-318\%20LV\%20RT\%20IPPHEAE\%20ASU\%20Survey\%20Latvia.pdf

Stapleton, P. (2012). Gauging the effectiveness of anti-plagiarism software: An empirical study of second language graduate writers. Journal of English for Academic Purposes, 11(2), 125-133. https://doi.org/10.1016/i.jeap.2011.10.003

Sutherland-Smith, W. (2005). Pandora's box: Academic perceptions of student plagiarism in writing. Journal of English for Academic Purposes, 4(1), 83-95. https://doi.org/10.1016/j.jeap.2004.07.007 
Theart, C. J., \& Smit, I. (2012). The status of academic integrity amongst nursing students at a nursing education institution in the Western Cape. Curationis, 35(1), 27. https://doi.org/10.4102/curationis.v35i1.27

Thomas, E. E., \& Sassi, K. (2011). An ethical dilemma: Talking about plagiarism and academic integrity in the digital age. The English Journal, 100(6), 47-53. http://www.jstor.org/stable/23047881

Thorpe, M. F., Pittenger, D. J., \& Reed, B. D. (1999). Cheating the researcher: A study of the relation between personality measures and self-reported cheating. College Student Journal, 33(1), 49-59. http://go.galegroup.com/ps/i.do?id=GALE\%7CA62894053\&sid=googleScholar\&v=2.1\&it=r\&linkacces $\underline{\mathrm{s}}=$ fulltext\&issn $=01463934 \& \mathrm{p}=\mathrm{AONE} \& \mathrm{sw}=\mathrm{w}$

Vaka'uta, C. (2008). What does it mean when teachers plagiarise? Directions: Journal of Educational Studies, 27(2), 12-24. https://works.bepress.com/cf koyavakauta/4/download/

Valentine, K. (2006). Plagiarism as literacy practice: Recognizing and rethinking ethical binaries. College Composition and Communication, 58(1), 89-109. http://www.jstor.org/stable/20456924

Vogts, D. (2009). Plagiarising of source code by novice programmers a cry for help? Proceedings of the 2009 Annual Research Conference. http://dl.acm.org/citation.cfm?id=1632168

Whitley, B. E. (1998). Factors associated with cheating among college students: A review. Research in Higher Education, 39(3), 235-274. http://link.springer.com/article/10.1023/A:1018724900565

Wilkinson, J. (2009). Staff and student perceptions of plagiarism and cheating. Journal of Statistics Education: An International Journal on the Teaching and Learning of Statistics. http://eric.ed.gov/?id=EJ864328

Willen, M. S. (2004). Reflections on the cultural climate of plagiarism. Liberal Education, 90, 55-58. http:// files.eric.ed.gov/fulltext/EJ682589.pdf

Williams, K. M., Nathanson, C., \& Paulhus, D. L. (2010). Identifying and profiling scholastic cheaters: Their personality, cognitive ability, and motivation. Journal of Experimental Psychology. Applied, 16(3), 293-307. https://doi.org/10.1037/a0020773

Yardley, J., Rodríguez, M. D., Bates, S. C., \& Nelson, J. (2009). True confessions? Alumni’s retrospective reports on undergraduate cheating behaviors. Ethics \& Behavior, 19(1), 1-14. https://doi.org/10.1080/10508420802487096

Yeo, S. (2007). First-year university science and engineering students' understanding of plagiarism. Higher Education Research \& Development, 26(2), 199-216. http://www.tandfonline.com/doi/abs/10.1080/07294360701310813

\section{BIOGRAPHIES}

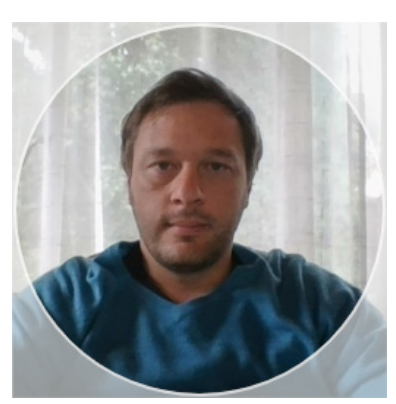

Frederik Hattingh is a lecturer at Tshwane University of Technology. His research interests include Living Labs, Virtualization and Plagiarism detection. Other areas of interests include Open Source Software and emerging technologies.

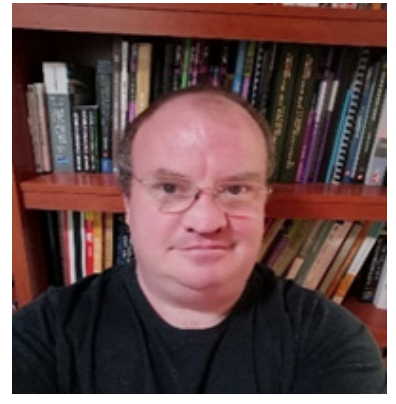

Bertie Buitendag is a lecturer at the Tshwane University of Technology in Pretoria, South Africa. His core research area includes ICT Knowledge support for emergent farmers and Living Labs, SMART LL operations and knowledge management. Other areas of interest include the: Semantic Web, (WEB 3.0) and WEB 2.0, and ICT's for community upliftment. 


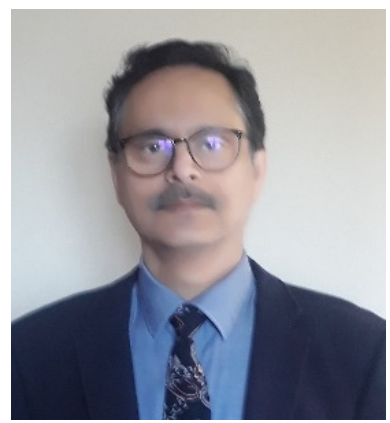

Manoj Lall is a senior lecturer in the department of Computer science at Tshwane University of Technology, Pretoria, South Africa. He obtained a doctoral degree in Computer Science from the University of South Africa in 2013. His research interests include Formal methods, Machine learning, and Agent based modelling. He has published over thirty international refereed conference and journal papers. 